\title{
Clem Seecharan
}

Finding Myself: Essays on Race, Politics \& Culture. Leeds: Peepal Tree Press, 2015. 338 pp. (Paper £19.99)

Finding Myself consists largely of essays that Clem Seecharan published between 1988 and 2011 on topics dear to his heart. For those who are familiar with his work it will come as no surprise that the book covers the history of East Indians in British Guiana/Guyana, nation building, and cricket, and engages with Caribbean writers and intellectuals, including V.S. Naipaul, Martin Carter, Walter Rodney, and C.L.R. James. The volume is divided into four parts: "Introduction," "In Search of Me," "Locating Cheddi Jagan," and "Miscellaneous Pieces: Rodney, James and Madray."

The lengthy introduction, "Tiger in the Stars': Ian McDonald and My Retrieval of Self-Belief," is the only original chapter, and provides a strong opening. An appraisal of the poet and thinker Ian McDonald, who was a guru to Seecharan, it is also a poignant autobiographical portrait. "This collection of essays, like much of what I have written over the last twenty-five years, owes much to his example and inspiration" (p. 11). The relationship started with a five-minute radio talk by McDonald in 1985 , entitled "Tiger in the Stars," which "rekindled my interest in my research and gave me the will to turn my life around" (p. 14). And it provided the title for his dissertation on the achievements of former indentured laborers. Seecharan views his research as "redemption in the eyes of my ancestors, who had made immense sacrifices to give us a better life" (p. 16). The introduction's second part is constructed around the letters written between Seecharan (now British-based) and McDonald between 1986 and 1990, the year the Ph.D. thesis was completed. Besides explaining the travails of a doctoral student, the letters give an interesting glimpse of Guyana's cultural life in the immediate post-Burnham years.

Part Two focuses on Seecharan's research on India and East Indians. A recurring theme is the role of escapism in coping with the harsh reality of Guyana. "The golden age of the Ramayana met the extravagant promise of El Dorado" (p. 76). Seecharan partially punctures the myth; he repeatedly quotes V.S. Naipaul's assertions that Guyana has always been a land of fantasy. Yet he argues that the East Indians' accomplishments are to a certain extent based on their "enduring engagement with their ancestral land, however imagined their conceptualization of that land and its legacy" (p. 82).

In Part Three Seecharan discusses Martin Carter's poetry of protest and the anticommunism and cultural idealism of Balram Singh Rai (Guyana's first minister of Home Affairs whose term was short-lived due to Jagan), but above all he uses his scalpel to dissect Cheddi Jagan and his politics, characterizing

(C) ROSEMARIJN HOEFTE, 2017 | DOI: 10.1163/22134360-09101047

This is an open access article distributed under the terms of the Creative Commons 
him as indefatigable and honest, politically inflexible, unable to forge alliances, and doctrinaire. He doesn't mince words: Jagan "made a fool of himself" while visiting President Kennedy in 1961 (p. 78), and his allies were "mediocrities, including party hacks whose intellectual nullity was compounded by their moribund Marxist creed" (p. 79). All this meant that Jagan put himself on the sidelines, excluded from power. Long-term rival Forbes Burnham and his party don't fare much better and are put down as massive hypocrites. The conclusion (written in 2005) cannot come as a surprise: "History and time are not on the side of this sad country! The Marxist ideological experiments of Jagan and Burnham were an unmitigated disaster. A nation is still not in the making: it remains a poor, environmentally hazardous land, mired in racial hatred, with its most educated and skilled in exile" (p. 200).

The final part is, as its title indicates, a mixed bag-a book review of Brian Moore's Cultural Power, Resistance, and Pluralism from 1995; an introductory essay from a volume on Walter Rodney by Eusi Kwayana; an assessment of the young C.L.R. James from Moving Worlds; and an interview with the Guyanese cricketer Ivan Madray from Indo-West Indian Cricket by Frank Birbalsingh and Seecharan.

Because most of it was previously published, Finding Myself is inevitably somewhat fragmented and repetitive, but a number of issues clearly show the foci of Seecharan's research and concerns: the millennial El Dorado, the elusiveness of a Guyanese nation and identity, Guyanese postwar politics, and, of course, cricket. As he puts it, "the writing of history ... must not be shackled by the imperatives of any cause. The historian should not have to look over his shoulder, and must feel free to slaughter sacred cows, if necessary" (p. 31). Clem Seecharan has indeed slaughtered a few cows in his career, but probably never without drinking a glass of good red wine afterward.

\section{Rosemarijn Hoefte}

KITLV/ Royal Netherlands Institute of Southeast Asian and Caribbean Studies, 2300 RA Leiden, the Netherlands

hofte@kittv.nl 